Historic, Archive Document

Do not assume content reflects current scientific knowledge, policies, or practices. 


\section{WOODLAWN GARDENS GLADIOLUS}

E. C. SWARTLEY

STERLING, ILLINOIS

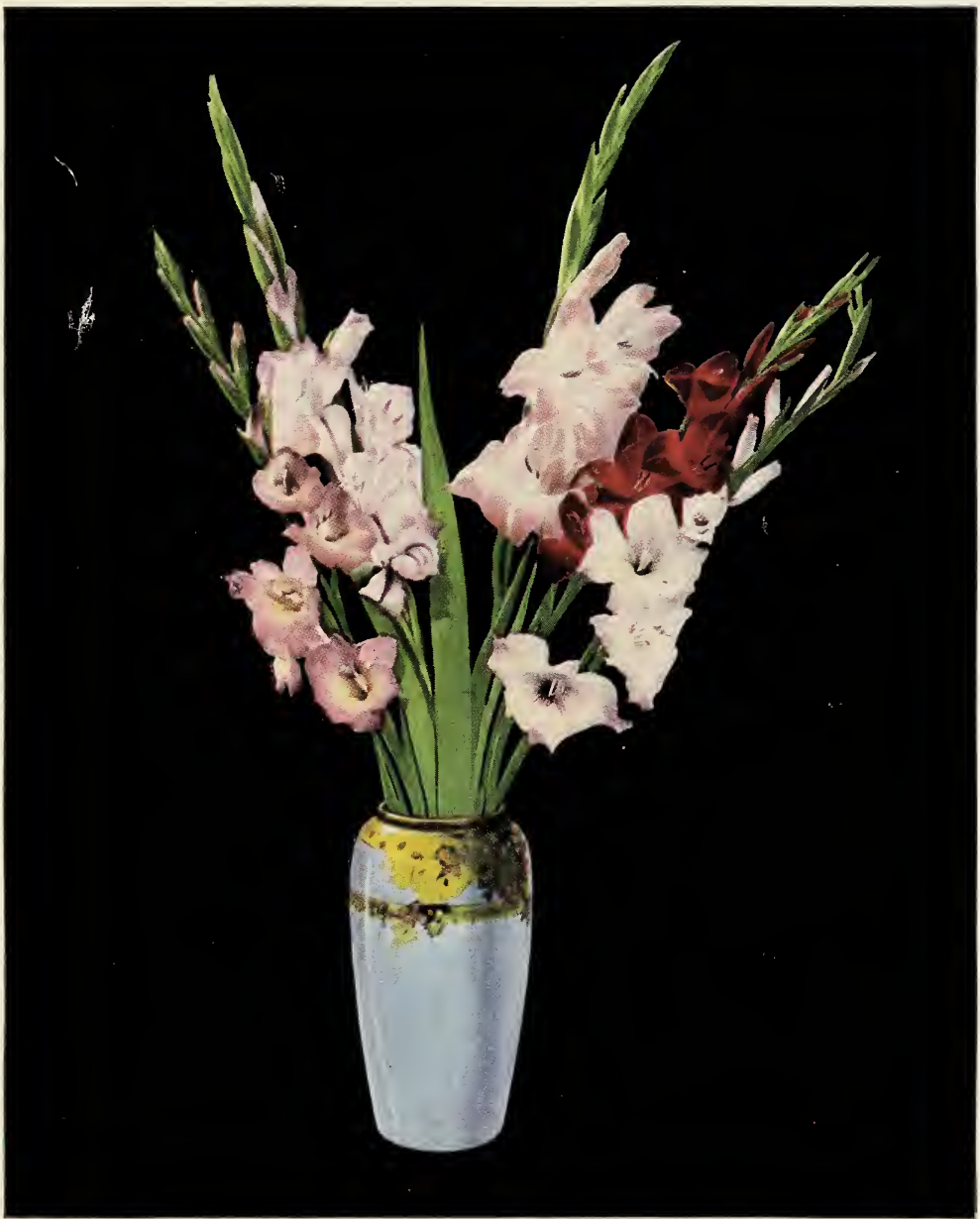

HAVE A HOBBY-GROW SOME GLADS 


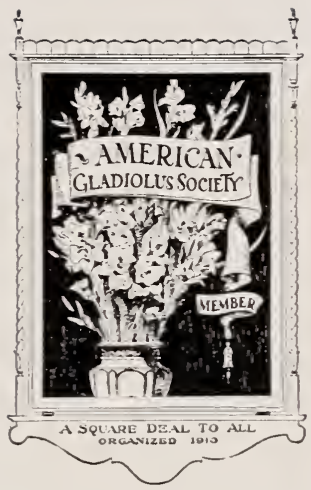




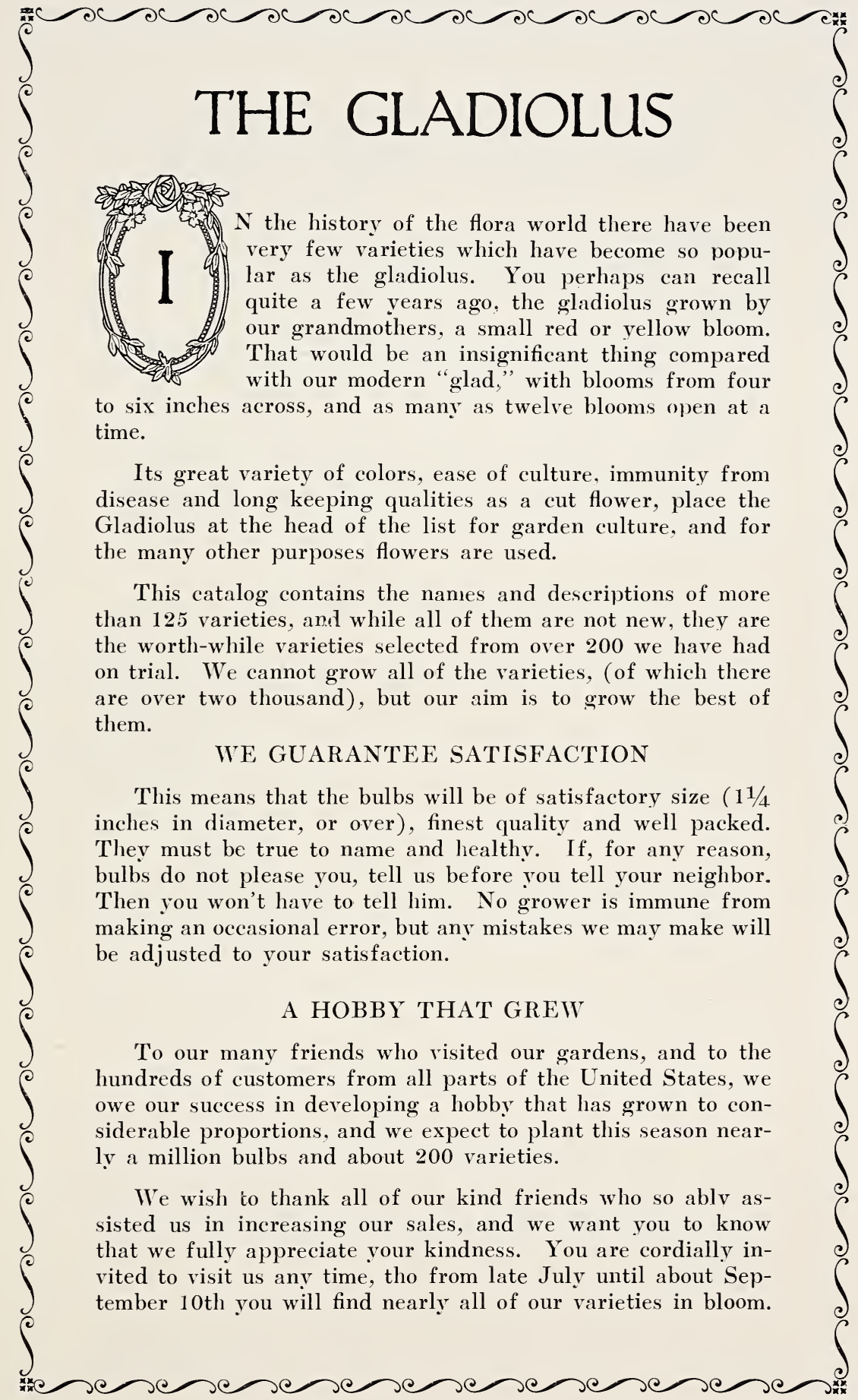




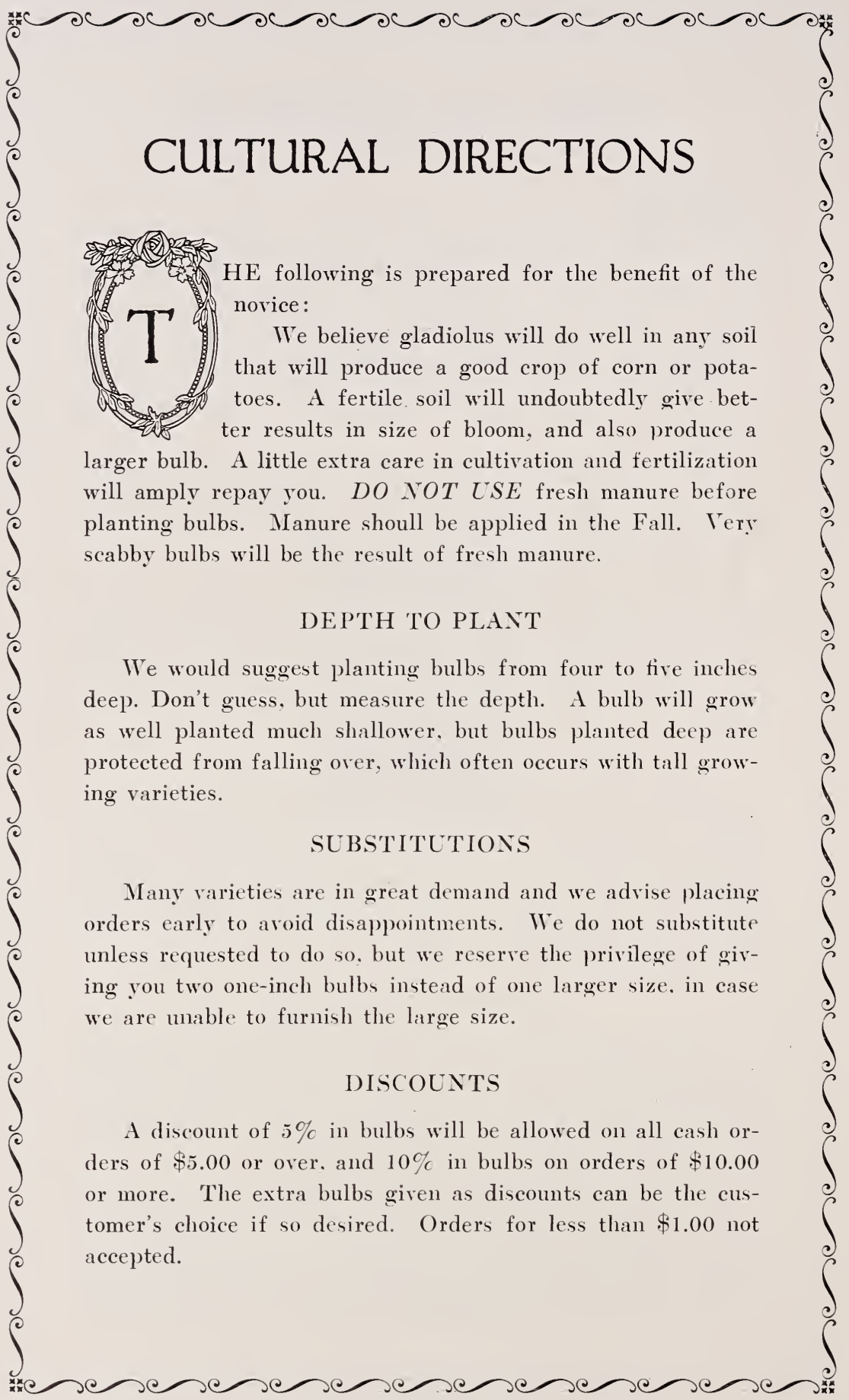


ALBANIA (Kemp)

Purest glistening white. Extra good commercial variety. Ruffled

ALICE TIPLADY (Kunderd)

Bittersweet pink, suffused scarlet at outer edges, and reverse, throat buff vellow. One of the best in the orange shades. A fine cut flower variety.

AMERICAN BEAUTY (Diener)

An attractive American beauty color. Throat creamy rellow, striped with ruby. Flowers large and many open at one time.

ANNIE EBERIUS (Diener)

Deep Rhomadine purple, shading into a very deep bordeaux center. An extremely attractive variety of exceptional merit.

ADELINE KENT (Diener)

An intensely ruffled variety of good size. of a soft rose pink color. Lovers of the ruffled trpe will like this one.

ALTON (Kunderd)

An exceptionally fine ruffled variety of a distinct orange shade. A beauty.

ADORATION

A very attractive flower. deep pink, with a tinge of blue on edge of petals.

ARABIA (Holland)

Refer to PERSIA for description.

BENGAL TIGER (Pratt)

In color and stripes. it resembles its name. You will be more than pleased with this one.

BYRON SMITH (Kunderd)

Light lavender, delicately suffused mallow purple, deeper at edge of petals. Throat a light rellow with etchings of mallow purple at base. I consider this the best of the light lavender class.

BUCKEYE (Kunderd)

Very large dark pink, darker spot in the throat.

BLUE JAY (Graff).

This variety comes nearly being a true blue with a pure white spot in throat. Extremely popular.

BREAK O' DAY (Bill)

A new one, pink blossoms with soft, creamy yellow blotch on lower petals. Outstanding on account of its earliness. 


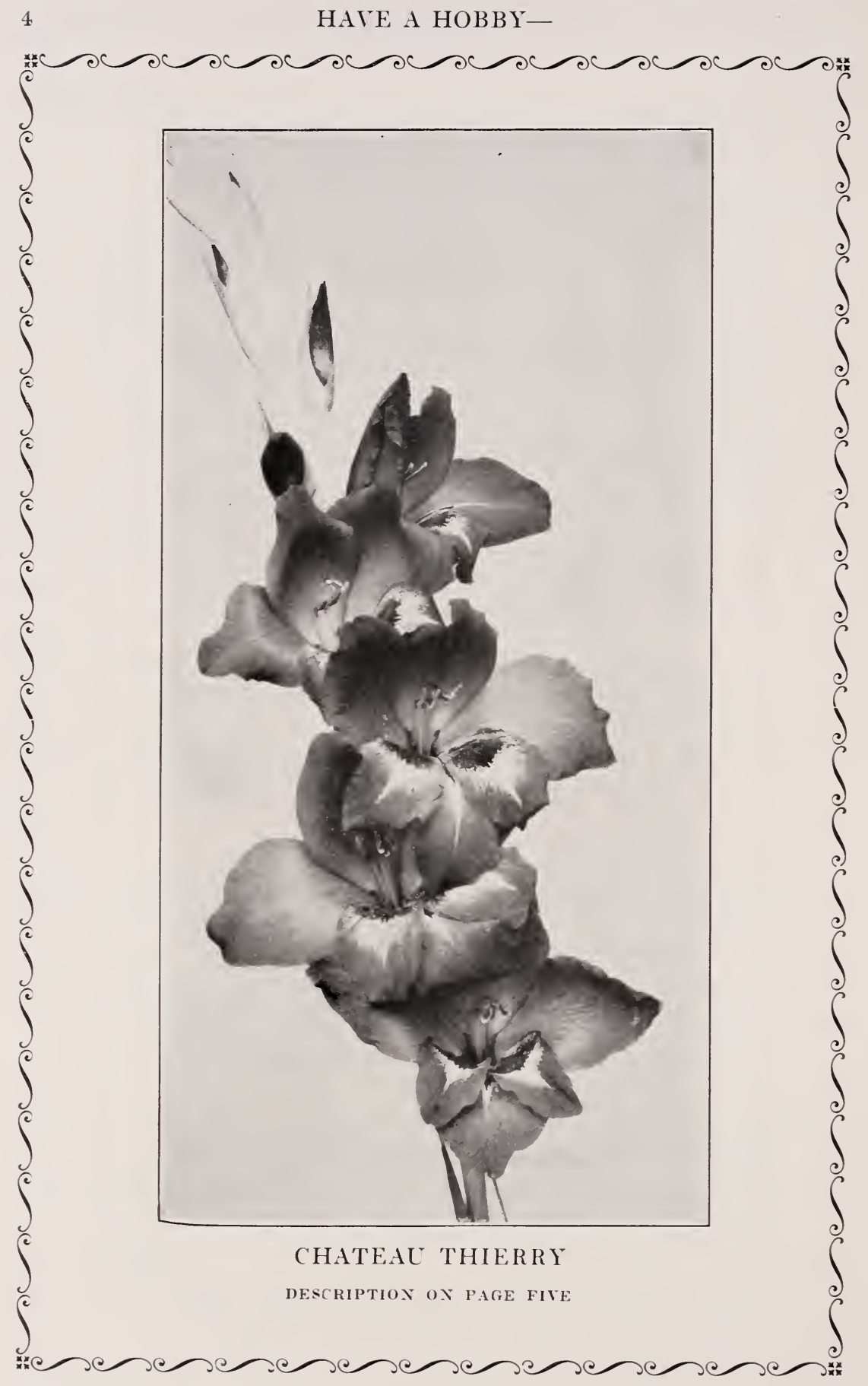




\section{x* GROW SOME GLADS \\ CARMEN SYLVIA (Prestgard) DACH DOZEN \\ CARMEN SYLVIA (Prestgard) .................................. $\$$.15 $\$ 1.50$ \\ This is an exceptionally fine white, large blooms, six}

open at once. Fine commercial variety.

CRIMSON GLOW (Betscher)

Beautiful, rich glowing crimson. Few can equal it in

its color.

CRINKLES (Diener)

Deep peach-blossom pink. It is intensely ruffled and resembles a double hollyhock. Extra fine.

CHA'TEAU THIERRY (Vos)

Bright cerise, a red blotch bordered with yellow on lower petals. Resembles Hollywood very much.

DR. ELKINS (Kunderd).

A true sport of Mrs. Frank Pendleton. Same large and showy flower, but the original rose pink has changed to white with large throat blotches of a fine shade of lilac blue.

DR. W. VAN FLEET (Diener).

Tall, very early, a magnificent shade of delicate rosepink. A general favorite.

DESDEMONE (Vilmoin)

Perhaps this variety is the most unusual color of any variety we are growing. Ashy-rose, striped lilac, large dark red blotch edged ivory white. Immense spike of large double row of flowers. With this variety in your garden you will be the envy of all your friends.

DORRIT'T (Kunderd)

Very large mottled, or speckled, deep pink. Verv attractive and the equal of Detroit, which it resembles in coloring.

DUCHESS OF YORK (Holland).

Large flowers of a purple blue color. Seedling of Baron Jos. Hulot. Vigorous grower and good multiplier.

E. J. SHAYLOR (Kunderd)

Large ruffled blossoms of a beautiful pure, deep, rosepink, on tall spikes.

ELIZABETH GERBERDING (Diener)

Shell pink, heavily ruffled, shading into rose on the outer edges. Center, pale canary and ruby. A very nice ruffled flower. 


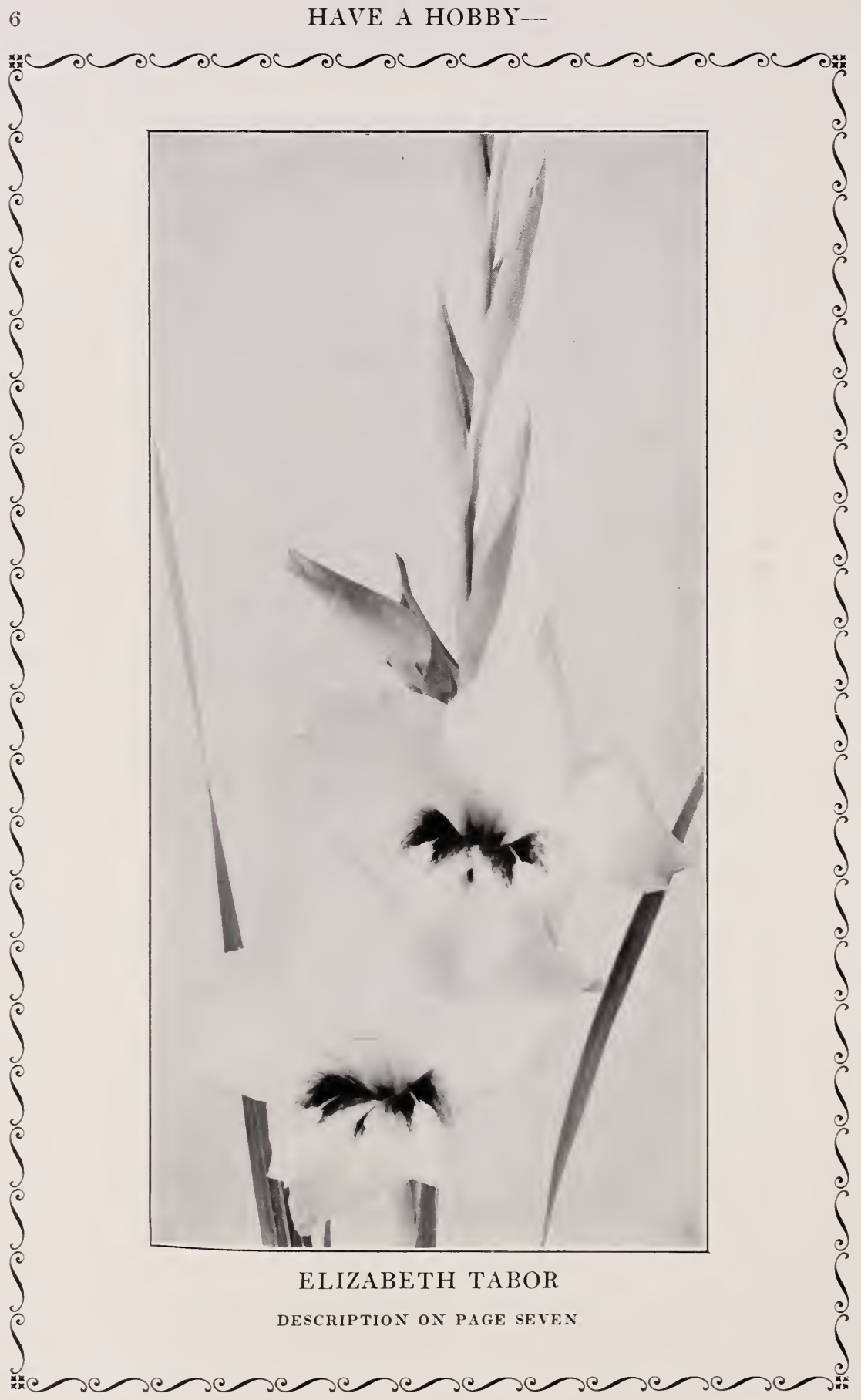


Each DOZEN

ELIZABETH TABOR (Hinkle) ….................................... . $\$ 51.50$

Winner of the first prize as the best new commercial variety in 1923. Extremely early, blooming in 60 days. Petals are a delicate rose-pink on white ground. lower ones bearing a rich dark crimson blotch. terminating in a diamond of soft yellow.

EMILY ASHE (Kunderd)

In my opinion, a poor white, though very nicely ruffled.. Blossoms of medium size. Small cerise blotch on lower petals.

ETENDARD (Lemoine)

A cream-white, French variety, with large, bright red center. A very beautiful and attractive variety.

\section{ELIZABETH SWARTLEY (Swartley).}

Named in memory of our mother. Color, a beautiful soft LaFrance pink blending into a milk-white throat. Its outstanding feature is its unusual color, never before seen in an early variety. We predict it will become one of the most popular commercial varieties of recent introduction. Stock limited.

EUGENE LEFEBRE (Lemoine)

An exceptionally fine French variety. Deep pink. with throat blotched purpleish Amaranth and cream. You will miss a beauty if you fail to get this one.

EVELYN KIRTLAND (Austin)

Rose-pink in color, with darker edges. Brilliant scarlet blotches on lower petals. Entire flower casts a glistening, sparkling luster. Very large flowers on a giant spike. A beautiful decorative variety.

\section{ELF (Diener)}

Lemon vellow buds, opening into snow-white flowers with lemon yellow lip. A perfect blend of two colors.

EXQUISITE (Kunderd)

An exceptionally fine glad of true American Beauty rose color, and all that its name implies.

Snow-white, without a trace of color. One of the most beautiful whites. 
FIRE RIBBON (Kunderd)

Tall, with many blooms open at one time. The spike is

a lone, fiery band of glowing red. Exceedingly rich, and strikingly showy.

FERN KYLE (Kunderd)

Palest cream with primrose colored throat. Very nicely ruffled and a winner in any company. A beauty.

FLORA (Velthny's)

A fine canary yellow, second only to Golden Measure. Best vellow for the price. Flower four inches in diameter. Strong, healthy grower.

GIANT NYMPH (Coleman)

LaFrance pink with creamy yellow throat. Verr large, wide open flowers. well arranged on stem. This is without doubt one of the very best of recent introductions.

GLENDALE (Daris Shelby)

American beauty red. a trifle darker than American beautr rose. Fine.

GOLD (Decorah Glad Gardens).

Pure golden vellow. A fine, clear self yellow. Perhaps the best yellow to date, and in my opinion is the finest florist rellow ever introduced.

GOLI)EN MEASURE (Kelway).

Straw rellow, lower petals suffused amber yellow. Large flowers and very vigorous grower.

GIANT MYRTLE

Soft pink on white ground. Large flower on long spike. Beautifully dainty.

GLADYS PLATHE (Diener).

Orchid flowering. lilac and red velvet blotches. Large flowers and a beautiful variety.

GOLDEN KING (Blads).

Clear, unfading yellow with a vivid crimson blotch in the throat. The flowers are good sized. well opened and well spaced on strong. straight spikes.

GOSHEN (Kunderd)

A fine flower of medium deep silvery rose-pink color. Large, showy rose-red blotehes. Very good.

GLORY OF KENNEMERLAND (Holland).

This is a very unusual flower. It is a very rich deep rose, with golden yellow blotch in throat. Flower very large, wide open bell-shaped. with rounded petals. 


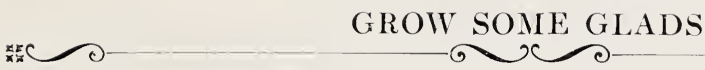

c

HALLEY (Velthnys)

Delicate, salmon pink, with creamy blotch and darker stripes on lower petals. A very early bloomer.

HELGA (Kunderd)

Fine salmon rose. Deeper rose and cream on white ground. A great improvement over Halley, which it somewhat resembles.

HERADA (Austin)

A beautiful sparkling mauve, with deeper shadings in throat. Very unusual and attractive color, and a general favorite.

HOOSIER (Kunderd)

A giant flower of finest salmon rose. Throat blotches as large and as beautiful as in Mrs. Frank Pendleton. Color of blotches violet maroon.

HENRY C. GOEHL (Fischer).

Large, open, creamy white flowers, with a beautiful red blotch. A new and wonderful variety.

HOLLYWOOD (Shelley)

Beautiful, big scarlet blossoms, with gorgeous yellow throats. Tall spikes, and a wonderfully striking variety.

HELEN FRANKLIN (Kunderd).

A beautiful ruffled white, with violet purple penciling on lower petals. A fine ruffled variety.

\section{IMMENSITY}

Tall, strong plant. Bright salmon color. Very large flowers and many open at a time. Very choice. One of Kunderd's prize winers.

INDIAN SUMMER (Kunderd)

A very massive ruffled variety of light lavender rosepink on white ground. A beautiful flower. Late bloomer.

INDIAN MAID (Kunderd)

A fine peach blossom pink, with beautiful darker throat. Very choice and distinct.

A beautiful salmon pink with a clear golden yellow throat. A good sized flower which does not show any signs of the primulinis type. 


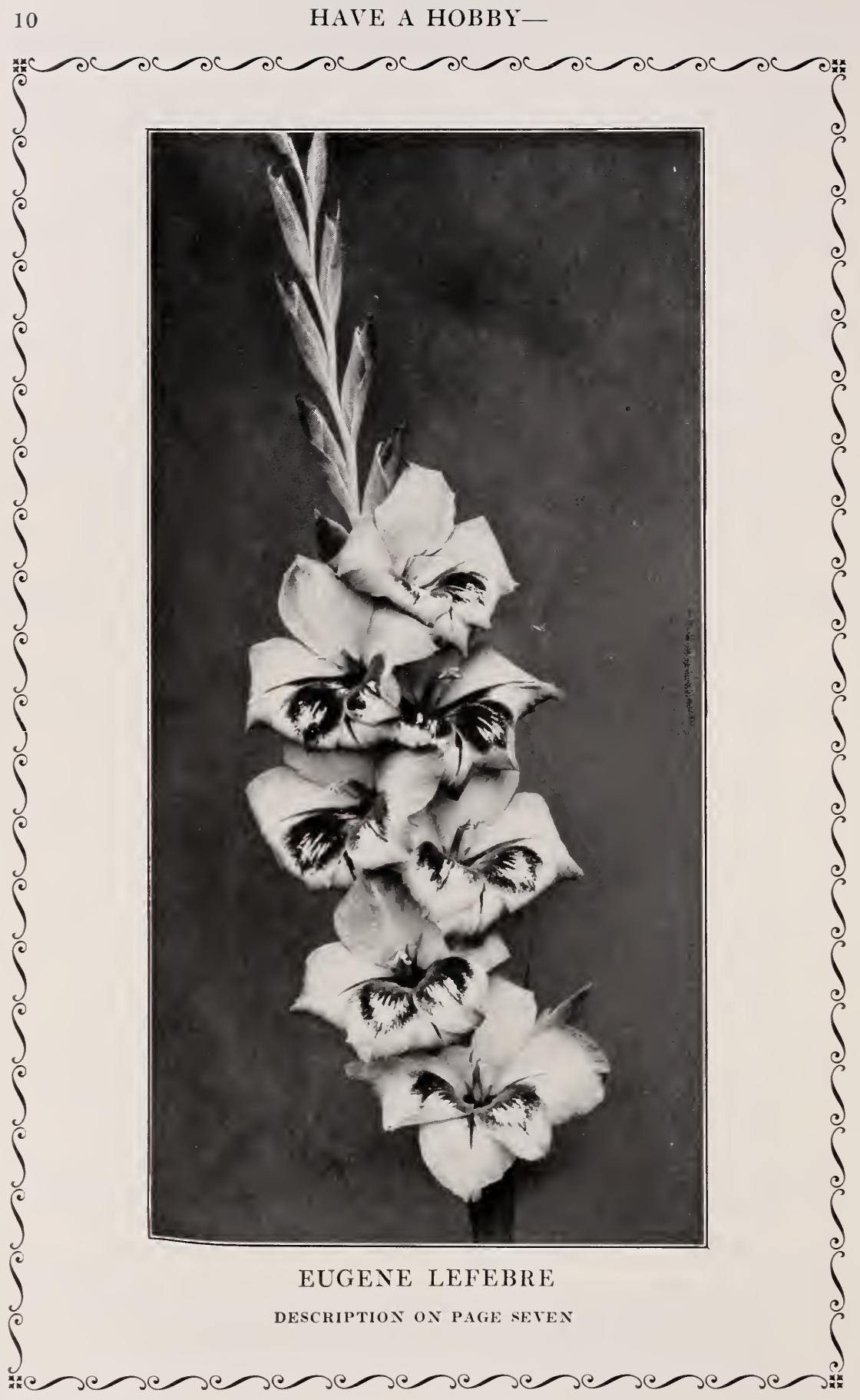


JENNY LIND (Decorah Glad Gardens)

The blossoms are the purest, softest shrimp pink, deepening to geranium pink at tips of petals. Throat beautiful, creamy yellow, with blotch of light yellow on reverse side of lower petals. As one lady exclaimed, this is a darling and should be in every collection.

JEAN DETAILLES (Lemoine)

A French introduction. Deep salmon flaked deeper, and with maroon throat. No mistake was ever made in growing this flower. Enormous flowers on tall spike. A georgeous variety

J. T. PIRIE (Kunderd)

A sort of mahogany brown with remarkable yellow bordered dark mahogany-brown throat. In a class by itself and should be in every collection.

JOY

LE MARECHAL FOCH (VanDeursen)

One of the largest of the light pinks, and one of the best of the Holland introductions. Early.

LOVELINESS

All that its name implies. A light creamy vellow, with a tinge of apricot. Flowers large, and a general favorite.

LOUISE (Wright)

A most beautiful lavender. Large flower, four and five inches across. Bright lavender, lighter toward center, blotch of velvety maroon down center. A prize winner.

LILLIAN WEBB (Diener)

Strawberry pink with carmine velvety center, overlaid with maroon and brownish stripes. The stems are slender and give the appearance of a lily.

LONGFELLOW (Decorah Glad Gardens)

LaFrance pink. A wonderfully pleasing color. Many large, wide open flowers. Tall, slender, wiry stem. Excellent for cutting. Has made a great hit the last two seasons.

LUCETTE (Bill's)

Pure white except back of petals carry a trace of phlox pink. which imparts an alluring orchid sheen to the flowers. Lower petals also have a dainty subdued feather of soft phlox pink. 


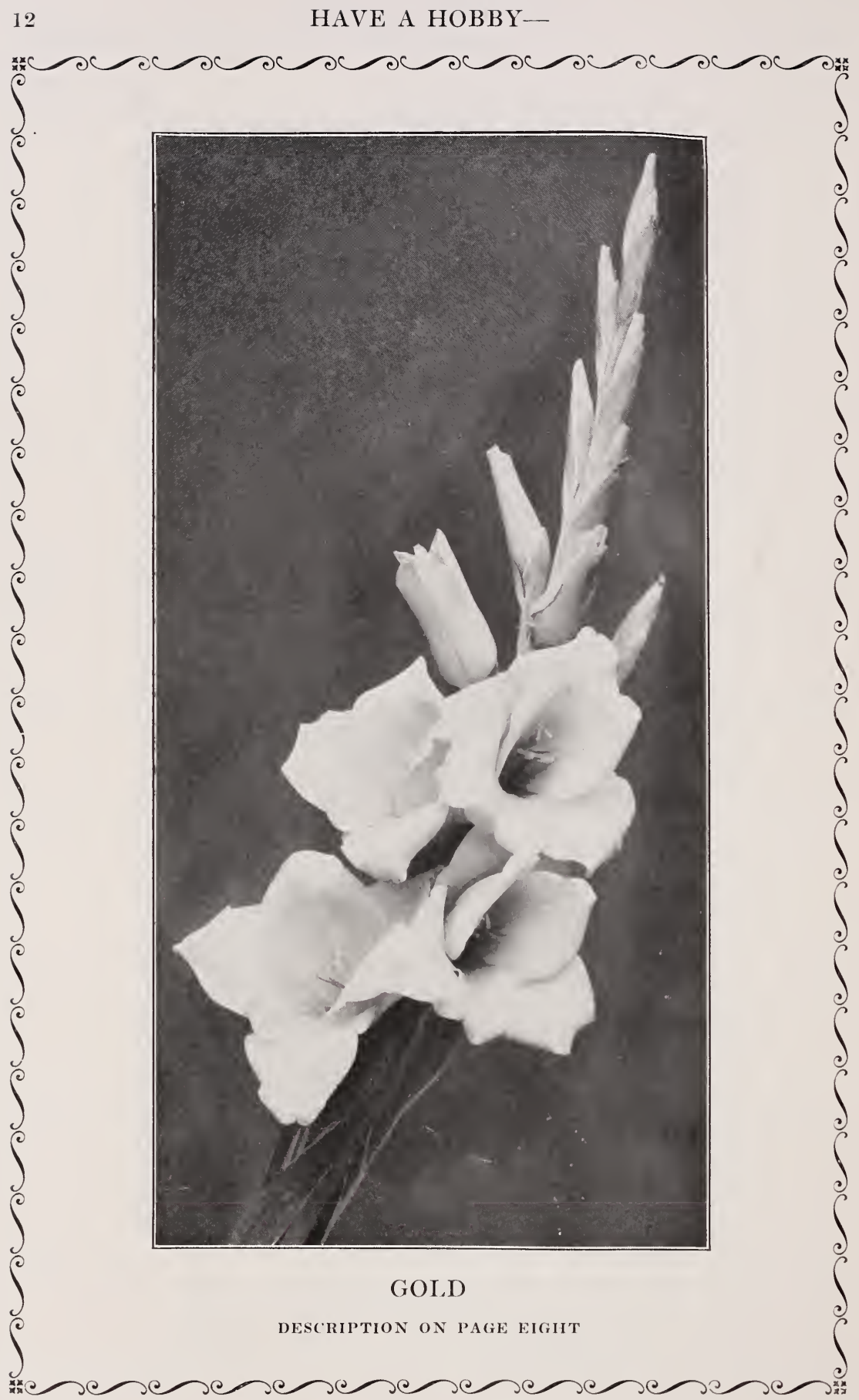




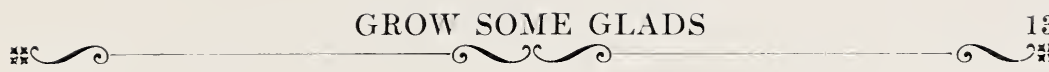

LOS ANGELES (Houdyshel) _.................................... $\$ .35 \quad \$ 3.50$

A charming varietr. Shrimp-pink, tinted orange, with an orange tinted stripe in throat. A cut-andcome-again variety. Something unusual, and a wonderful cut flower.

MARIETTA (Metzner)

A winner among the salmon colored varieties. Large, soft salmon pink, with a pleasing blotch of darker shade in throat.

MARIE KUNDERD (Kunderd).....

Conceded to be the best pure white ruffled cariety. Early.

MASTERPIECE (Kunderd)

A large size bloom of American beauty rose color. Beautifully ruffled. Exquisite and Mrs. Arthur are better, and same color.

MARY FENNELL (Kunderd)

A beautiful light lavender tinged with soft pink. Has soft primrose rellow throat. Flowers large and wide open. A most delicately colored flower.

MARSHAL FOCH (Kunderd)

The king of the pinks. Ruffled flowers of large size. A beautiful salmon pink, striped with a deeper salmon toward edge of petals. Don't fail to grow this variety.

MRS. DR. NORTON (Kunderd)

This variety heads the list in the light pink class. Light pink in color, shading to a yellow center. An exquisite combination in colors.

MRS. FRANK PENDLETON (Kunderd)

Large flowers of delicate pink with large blotch of deep red in throat. An old variety, but hard to beat.

MRS. FRANCIS KING (Coblentz)

One of the old standbys. Orange scarlet blend. Very large flowers nicely placed on tall, stately spikes. Fine decorative variety.

MRS. H. E. BOTHIN (Diener)

Light geranium pink, heavily ruffled. Tall, straight spikes. A lovely combination, and do not fail to include this in your collection. 
MRS. LEON DOUGLAS (Diener)

Winner of many prizes for the largest bloom in existance. Ground color begonia rose. striped with flame and scarlet. Lip pale lemon. This without exception is one of Diener's best productions.

MURIEL (Pfitzer)

From a few feet distance it would be difficult to distinguish any difference between this variety and Geraldine Farrar. A true lilac blue. slightly darker at tips of petals.

MING TOY (Kunderd)

One of the worth-while primulinus varieties. Verr large flower with deep buff-yellow throat. Buff in color, and vere odd and unique. Fine.

MISS MAUD FAY (Diener).

Pale Amaranth pink with a light stripe running tilıru the center of each petal. The edges of the petals shade into Tyrian pink. Flowers are very open and large.

MARY PICKFORD (Kunderd)

Flower and spike of most delicate creamy white. Throat finest, soft sulpluur vellow. Stem and calix also white.

MRS. ARTHUR MEEKER (Kunderd)

Exceptionally fine, rich deep American beanty color. A very beautiful and unusual variety.

MRS. WATT (Crawford)

Beautiful clear wine red. Fine flower. and strong. vigorous grower.

MRS. JOHN R. WALSH (Diener).

Heavily ruffled flesh pink. Three lower petals of flame scarlet, shading into dark ruby in the throat. Flowers very large.

MRS. F. C. PETERS (Fischer)

Fine rosy lilac blossoms with softest crimson blotcl. .25 and many open at one time. Resembles an orchid in color. A choice variety which everyone admires.

NANCY HANKS (Salbach)

Very rich peach red to orange pink with prominent grenadine tongue. Wide open flowers much on the order of Alice Tiplady, but larger and of taller growth. Also slightly lighter in color. 
EACH DOZEN

ORANGE GLORY (Kunderd)

$\$ .15 \$ 1.50$

Beautiful, intensely ruffled orange colored blossoms with lighter throat. A very rich and striking color. Wonderful variety.

POLLYANNA (Decorah Glad Gardens)

A clear yellow and nicely ruffled. A beauty.

PRINCE OF WALES (Holland)

Softest salmon with an apricot undertone. Still leads as one of the best salmon color varieties.

PERSIA (National Bulb Farms).

A rich, deep, mahogany black-red, buds almost black. Its unusual color immediately attracts attention, and it is the most popular variety we are growing.

PINK CLOUD (Kunderd)

A large, distinct and showy ruffled variety. Usually from five to seven soft rose-pink blooms open at one time. A very beautiful deep rose throat.

PELLA (Kunderd)

Very beautiful early rose-pink. Very good.

PINK WONDER (Coleman)

An exceptionally large light pink. You will like this one.

PRIDE OF HILLEGOM (Holland)

Very beautiful scarlet. Large flowers well placed on spike.

PRIDE OF LANCASTER (Kunderd)

Beautiful brilliant orange-salmon, with a deeper orange throat. Very nicely ruffled.

PURPLE GLORY (Kunderd)

A beautiful ruffled variety. Deepest velvety maroon red, with blotches almost black. Gorgeous, and a variety you will be proud to display.

PYTHIA

A very large, bright red, and one of the finest of its color.

PEARL OF CALIFORNIA (Kingsley).

Soft LaFrance pink, blending to a rosy white throat. Each spike contains from 25 to 32 buds. Flowers five inches in diameter.

PINK PERFECTION (Hopman)

A very bright pink, self color. Flowers perfectly placed on a long wiry stem. but has a fault of manv spikes coming crooked. 


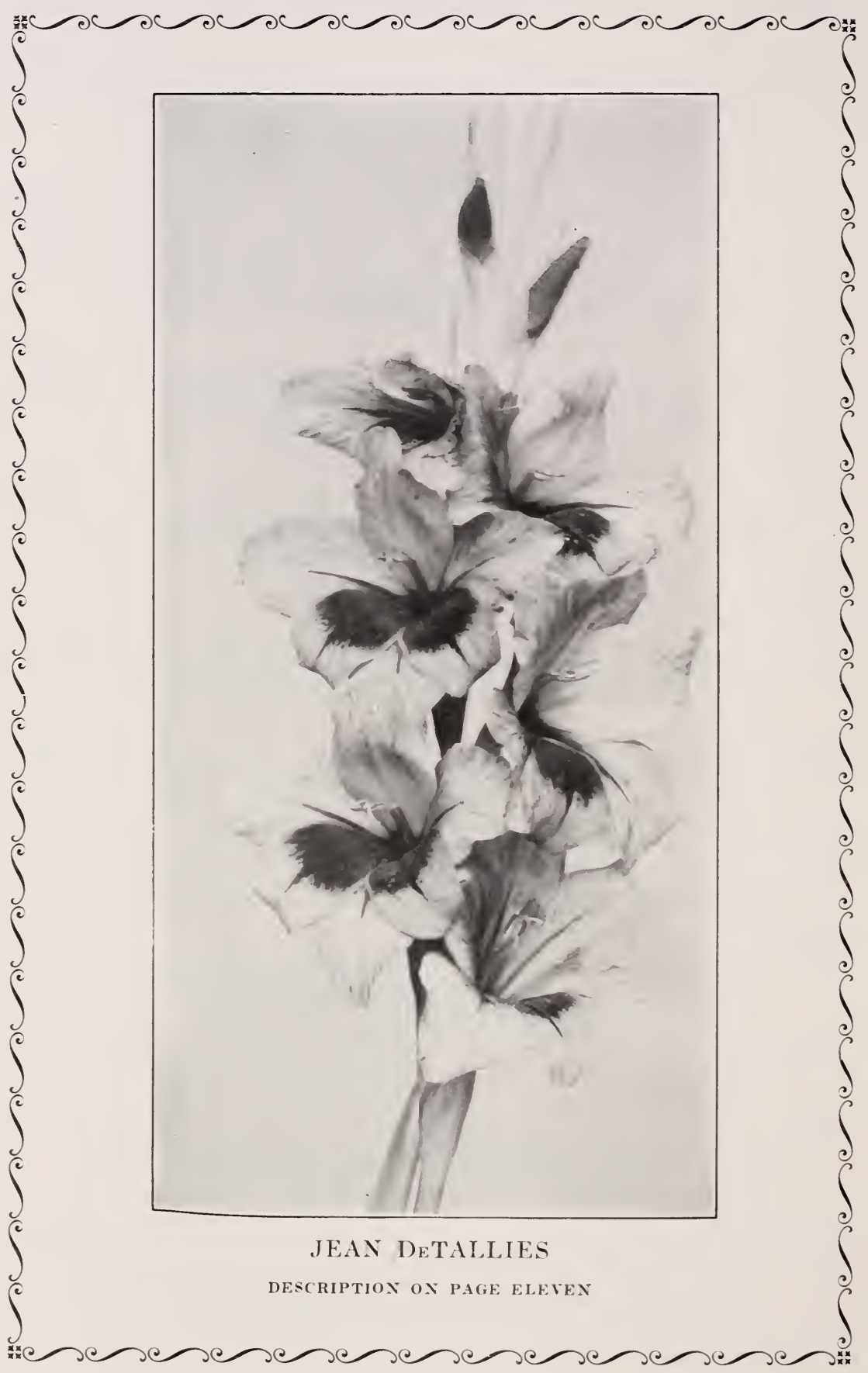


RICHARD DIENER (Diener)

DOZEN

A pure geranium pink with a sprinkling of light ruby in the creamy yellow center. Large flowers and many open at a time. Large, graceful spike and a sensation in the pink class.

ROMANCE (Kunderd)

Large orange, salmon-rose, red and vellow throat. Wine blue bordered petals. An unusual and odd colored beauty.

ROSE ASH (Diener)

Extra strong, large plant. Corinthian red shading into ashes of roses on the outer edges. Lower petals light yellow speckled with ruby. Flowers large, and a variety that is sure to please you.

1910 ROSE (Kunderd)

Deep rose-pink shading to rose-red. Lower petals slightly mottled at times. White center line. First to bloom and a very popular florist variety.

SANFORD, or Queen of the Night (Metzner)

Deep maroon, almost black. Very large flower.

SALMON BEAU'TY (Kunderd)

One of the few primulinus varieties we consider worth growing. Deep salmon with salmon yellow throat. Nice size flowers on a tall, straight spike.

SCARLANO (Kunderd)

Light, bright orange-red. Finely ruffled. A large number of these in bloom looks like a bon-firc.

SCARLET PINCEPS (Kunderd).

Large scarlet, self color. Beautiful, and a variety you should grow.

SCARLET WONDER (Groff)

Mammoth, pure deep scarlet flowers on tall, straight spike. This variety is conceded to be the largest scarlet to date.

SWEE'T LAVENDER (Coleman) An exceptionally fine early variety. Light lavender, deeper in throat, with purple blotch. A beauty.

SUNSET (Diener)

A very early coral pink, and a very lovely variety. Large flowers.

SYDONIA (Holland)

A most unique and distinctive flower. Violet, slightly lighter in throat. 


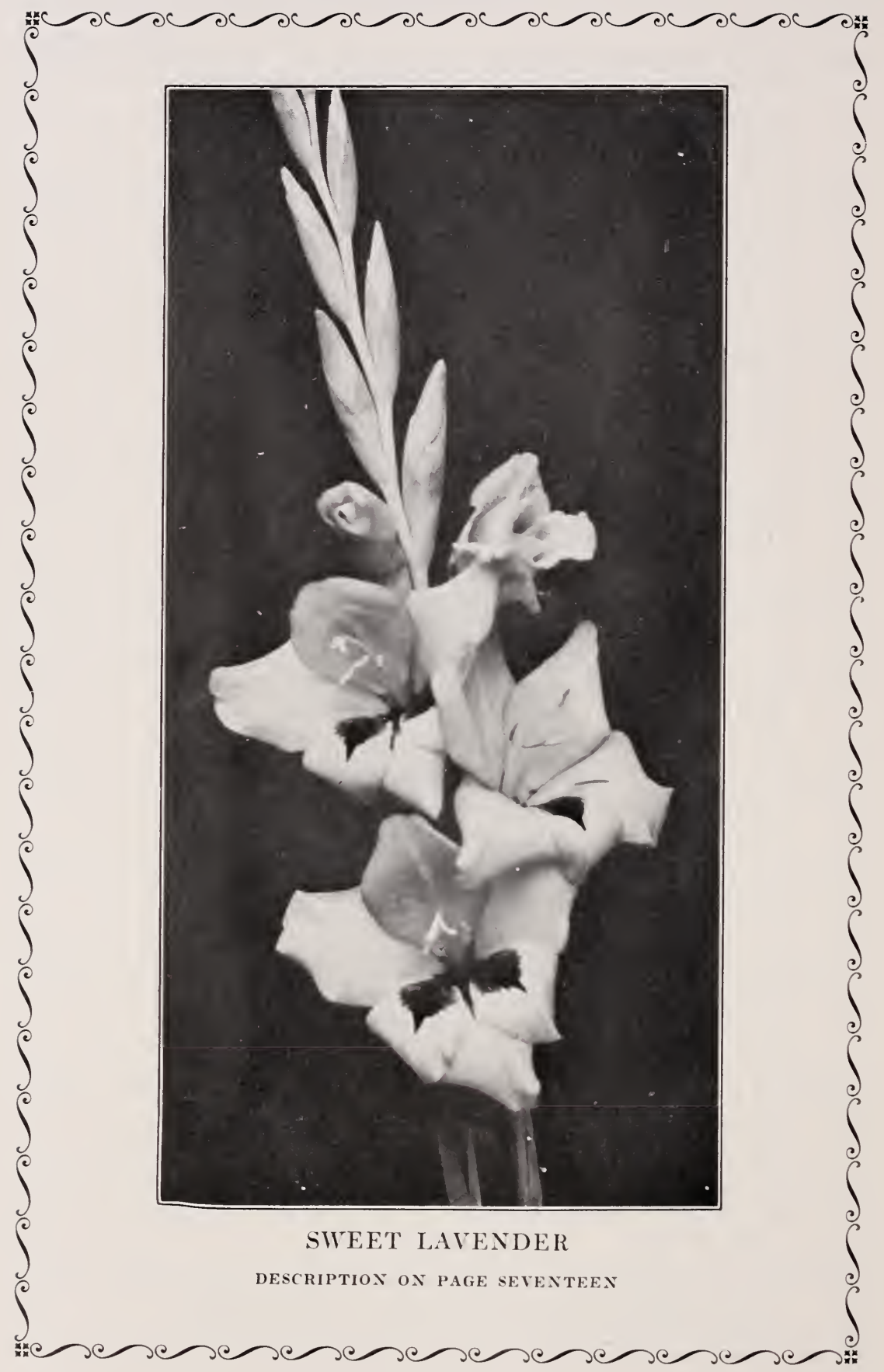



SANS PARIEL (Vilmorin)........................................ Large flower and
Apricot pink with white throat.
perfectly gorgeous.

SULPHUR GLOW (Kunderd)

A beautiful shade of vellow. Many well expanded. intensely ruffled flowers open at one time.

SIR ROGER CASEMENT (Diener)

TYRIAN BEAUTY (Kunderd)

Magnificent spike of large flowers of pure Trrian rose, near American beauty rose. Upper petals slightly lighter. Tall, strong grower, and it has no competition in this color.

TYCO ZANG (Austin) 1-inch bulbs

Blooms are of a beautiful salmon pink, with a brilliance unsurpassed and possibly unequaled under electric lights. Flower usually measures 5 inches in diameter and has several blooms open at one time. Grand new variety you ought to have.

VEILED BRILLIANCE (Austin)

Brilliant blooms of salmon-pink with creamy throat. tinted gravish blue. having the appearance of being thinly veiled. Wonderful effect, new and different. Flowers 5 to 6 inches in diameter and ten open at a time. Increases well.

WILBRINK (Holland)

This is a sport of Halley and as early as Halley. It is a creamy pink with soft yellow blotch on lower petals. A distinctive flower.

WHITE GIANT (VanMeerbeek)

Very large flowers of pure white. Resembles an Easter lily. Very good.

WHITE GLORY (Kunderd)

Lovers of the ruffled type of blooms will fall in love with this one. Georgeous ivory white with a touch of iris-blue in throat. Fine as a delicate iris.

IV. H. PHIPPS (I)iener)

One of the most beautiful flowers ever produced br Diener. LaFrance pink overlaid with light rose-salmon. Lower petals delicately striped with ruby. Enormous flowers, tall spikes, and as many as 16 to 20 blooms open at once. 


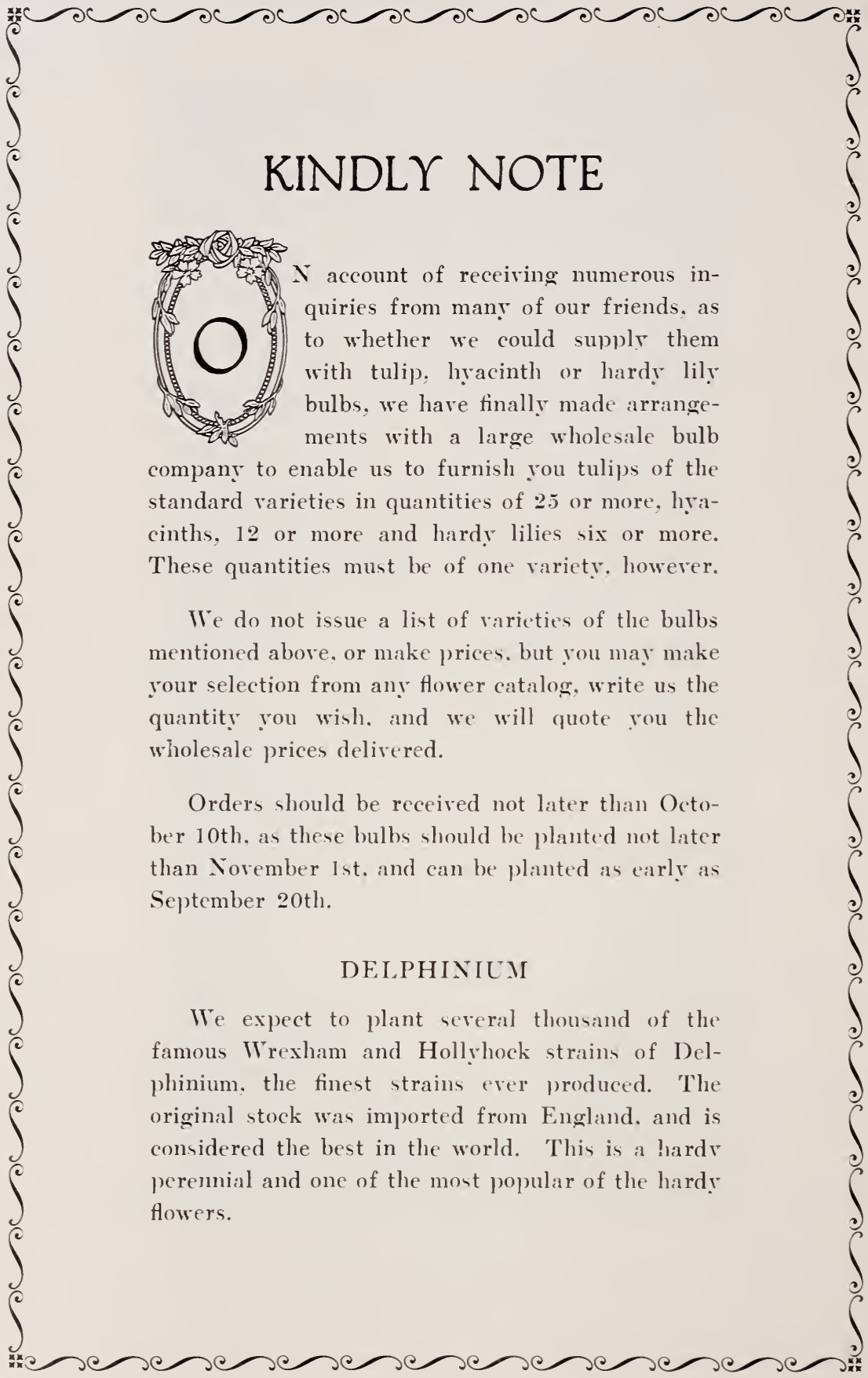




\section{3}

\section{Woodlawn Gardens}

111

E. C. SWARTLEY, Proprietor

STERLING, ILLINOIS

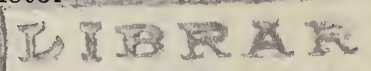
-

GROWERS OF NEW AND STANDARD

\section{GLADIOLI}

\section{WHOLESALE PRICE LIST}

\section{1}

Price per 1000 unless otherwise noted. 250 at 1000 rate. Write for price on Bulblets.

Annie Eberius

B. Smith

Carmen Sylvia

Crimson Glow.

E. Faber (per 100)

Eugene Lefebre (per 100).

$\times$ Glendale (per 100)

Gold (per 100)

Marshall Foch (per 100).

Mrs. Dr. Norton.

Mrs. H. E. Bothin

Pink Wonder

Rose Ash

Sweet Lavender (per 100)

Scarlet Wonder (per 100)
No. 1 No. 2 No. 3 No. 4 No. 5

$\$ 25.00 \quad \$ 20.00 \quad \$ 16.00 \quad \$ 12.00 \quad \$ 9.00$

$35.00 \quad 30.00$

$\begin{array}{lllll}30.00 & 25.00 & 20.00 & 15.00 & 10.00\end{array}$

$25.00 \quad 20.00 \quad 16.00$

$\begin{array}{lllll}8.00 & 6.50 & 5.00 & 4.00 & 3.00\end{array}$

8.00

6.50

5.00

4.00

4.00

3.00

2.50

2.00

5.00

4.00

3.25

$5.00 \quad 4.00$

$25.00 \quad 20.00$

30.00

25.00

20.00

15.00

10.00

$\begin{array}{lllll}30.00 & 25.00 & 20.00 & 15.00 & 10.00\end{array}$

$\begin{array}{lllll}30.00 & 25.00 & 20.00 & 15.00 & 10.00\end{array}$

$4.00 \quad 3.25$

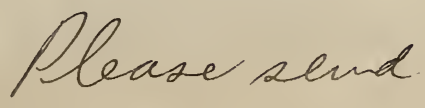

5.00 


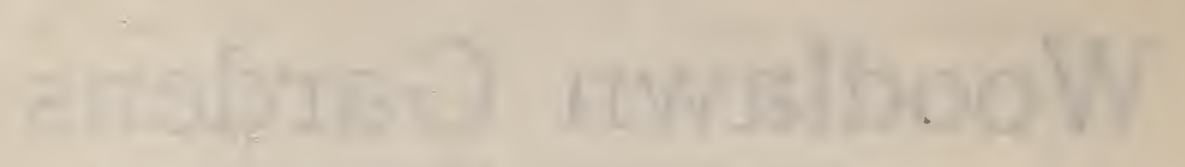

Golga.Ja 


\section{SPECIAL COLLECTIONS}

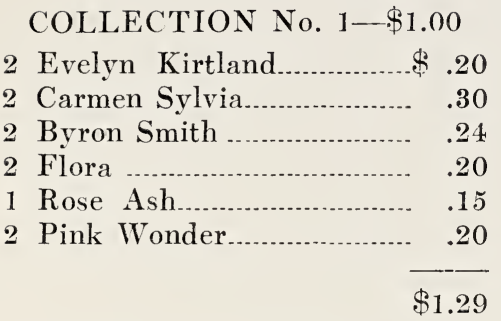

COLLECTION No. 2--\$1.00

2 Sweet Lavender.................. \$ .30

2 Gold ................................. .40

2 Mrs. Dr. Norton................ .20

2 Pink Wonder..................... .20

1 Hoosier ................................ .20

$\$ 1.30$

COLLECTION No. $3-\$ 2.00$

2 Hoosier …….......................... 40

3 White Giant ..........................5

2 Romance …......................... .50

2 Persia ….........................

2 Alice Tiplady ....................... .20

2 Glendale ….........................

$\$ 2.35$
COLLECTION No. $4-\$ 2.00$

2 Tyrian Beauty ................. $\$ .40$

2 Marshal Foch ................... . 30

2 Marie Kunderd................. . .30

2 Glendale ............................ . .30

1 Mrs. Leon Douglas............ .50

3 Gold .......................................

$\$ 2.40$

COLLECTION No. 5- $\$ 3.00$

3 Eugene LeFebre................ .75

2 Jean DuTailles.................. .60

3 Tyrian Beauty.................... . 60

2 Purple Glory ....................... .50

2 Persia ……........................5

2 Romance …......................... .50

$\$ 3.45$

COLLECTION No. 6-\$5.00

1 Tyco Zang ....................... $\$ 1.50$

1 Break O'Day ..................... 2.00

1 Stanford …........................ .75

1 Sans Pariel ...........................

2 Los Angeles....................... $\quad .70$

$\$ 5.70$

$\$ 3.00$

Fine varieties of mixed bulbs, per 100 .

\section{THE GIFT BOX}

\section{SPECIAL PRICE OF $\$ 1.00$}

We are making up a special gift box which contains the greatest value we have ever offered in a collection of "glad" varieties. This box contains 15 distinct varieties of our most popular blooms (not named), and to the novice in growing gladiolus this collection will be a revelation.

As an Easter remembrance, or as a gift to mother on Mother's Day, there is no other gift which could possibly give greater pleasure. and would also be a kind reminder of the donor when the "glads" are in bloom.

This collection will be packed in a very attractive box, and the wrapper will display the blooms in colors identical with the colors on our catalog.

A number of church societies and woman's clubs have taken advantage of our offer to dispose of gladiolus, and have realized some very nice profits from the sale of our bulbs. If you will write us for particulars we will be very glad to give you full details. 
